\title{
Katarina Ivon
}

Sveučilište u Zadru, Hrvatska

kivon@unizd.hr

\section{Zlatni danci Jagode Truhelke - primjer kroatocentričnoga kulturnoga imaginarija}

\author{
Izvorni znanstveni rad / original research paper \\ Primljeno / received 7. 4. 2015. Prihvaćeno / accepted 10. 7. 2015.
}

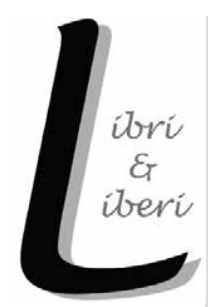

Poticaj radu misao je autora Povijesti hrvatske dječje književnosti (M. Crnkovića i D. Težak) kako su naglašeno hrvatstvo i religioznost Truhelkina djela bili loša preporuka u razdoblju obiju Jugoslavija za njegovo uvrštavanje u službenu lektiru te kako su njezina djela bila vrlo često vrednovana na izvanknjiževnoj osnovi. Na tome tragu interpretira se autoričina autobiografska trilogija Zlatni danci u kojoj se razabiru dominantni motivi i narativi koji svojom učestalošću pripomažu u rekonstrukciji i tumačenju njezina kulturnoga imaginarija, koji možemo atribuirati kroatocentričnim. Taj imaginarij autorica signalizira različitim postupcima: Aničinim didaktiziranim patriotskim ,tiradama“ naučenima u školi, opisom učiteljičine škole i salona, dječjom igrom bitke kod Sigeta (Hrvati nasuprot Turcima) te ispoviješću drvosječe Đorđa (Hrvata iz Istre) i njegovim znakovitim sudjelovanjem u Viškoj bitci. Važan je i element prostora koji, osim što ima integracijsku ulogu, postaje važnim pokazateljem kulturne samoidentifikacije. Analiza implicira kako imaginarij Zlatnih danaka ne reprezentira samo njihovu autoricu, već, u stanovitoj mjeri, i vrijednosti zajednice kojoj pripada.

Ključne riječi: kulturni imaginarij, Jagoda Truhelka, Zlatni danci, nacionalno markiranje prostora, hrvatska dječja književnost

\section{Uvod}

Poticaj za nastanak ovoga rada bila je misao Milana Crnkovića i Dubravke Težak iz knjige Povijest hrvatske dječje književnosti od početaka do 1955. godine objavljene 2002. u kojoj autori, govoreći o trolistu drugoga razdoblja hrvatske 
dječje književnosti (Ivana Brlić-Mažuranić - Vladimir Nazor - Jagoda Truhelka), konstatiraju kako su upravo Truhelkino naglašeno hrvatstvo i religioznost bili loša preporuka za službenu lektiru u usporedbi sa slavenstvom Vladimira Nazora i Ivane Brlić-Mažuranić. Autori navode kako se Truhelkino stvaralaštvo nakon 1945. nije preporučivalo te je često bilo vrednovano na izvanknjiževnoj osnovi. Kao primjer navode Slobodana Markovića, srpskoga stručnjaka za dječju književnost, koji na prvo mjesto stavlja njezin roman Zlatko (1934), dok vrijednost Zlatnih danaka (1918) negira njegovim neknjiževnim značajkama, ističući pritom kako one nisu nadživjele vrijeme svojega nastanka. Desetak godina prije u knjizi Dječja književnost (1990) Milan Crnković naglašava vrijednost Zlatnih danaka svrstavajući ih u najbolja Truhelkina djela. Prema njegovim riječima njihovo četvrto izdanje iz 1969. godine ,spašava od nepravednog zaborava jedno od dva snažna djela s kojima je hrvatska realistična dječja književnost započela i odmah u početku našla siguran put“ (1990: 129). Stjepan Hranjec u knjizi Hrvatski dječji roman (1998) također naglašava kako se o Truhelkinu književnome radu pisalo vrlo malo unatoč njezinoj važnoj ulozi u hrvatskoj književnosti, kulturi i školstvu. Autor, navodeći temeljne smjernice u Truhelkinu radu, posebno ističe fascinaciju činjenicom „da se u obitelji učitelja, češkog doseljenika i žene mu, mađarske Njemice, gajilo duboko, iskreno i plameno hrvatsko domoljublje“ (Hranjec 1998: 17). U pogovoru Zlatnim dancima objavljenima 1997. Milan Crnković naglašava kako se u Truhelkinome književnome djelu ,jasno i reljefno odražavalo hrvatstvo i katoličanstvo“ te kako su Jagodu Truhelku ,u nepovoljnom vremenu potiskivali iz školske lektire“ (1997: 275). Upravo ta misao bila je poticaj i Hranjecovu radu „Jagoda Truhelka: vjera kao tradicijska baština" objavljenome u knjizi Kršćanska izvorišta dječje književnosti 2003. godine. Hranjec navodi kako se umjetnost riječi ponekad procjenjivala izvanjskim mjerilima, odnosno o njoj je odlučivala politika, a ne književna kritika (2003: 54):

Primjera je, nažalost, otkada je umjetnosti (ne samo književnosti). Među njih ubrajamo i Jagodu Truhelku, zato što je isticala ono što naglašava i Crnković, domoljublje i vjeru, dakle ono što bijaše vodilja odreda svim hrvatskim književnicima, onima koji su svojim djelima, zapravo, gradili hrvatsku državnost.

Da je Truhelkin književni rad ostao po strani, svjedoči i podatak u knjizi Valentine Majdenić (2013) Regionalni tekst dječje književnosti. Autorica je ondje analizirala prisutnost slavonskih pisaca u osnovnoškolskim udžbenicima u dvama važnijim razdobljima hrvatske povijesti i književnosti. Prvo razdoblje od 1970. do 1989. obilježeno je hrvatskim proljećem i hrvatskim slomom, dok drugo razdoblje od 1990. do 2008. ponajviše obilježavaju osnutak neovisne Hrvatske i Domovinski rat. Jagoda Truhelka u prvome razdoblju zastupljena je sa svega deset 
tekstova u udžbenicima za osnovnu školu, dok je u drugome zastupljena s 53 teksta. Iako je udio gotovo svih slavonskih pisaca veći u drugome razdoblju, što je i logično zbog povijesno-političke situacije te aktualizacije istraživanja uloge prostora u suvremenim interpretacijama književnih tekstova, svakako te podatke valja ozbiljno uzeti u obzir pri pozicioniranju Truhelkina književna stvaralaštva. Navedeno predstavlja važan poticaj u pokušaju rekonstrukcije Truhelkina kulturnoga imaginarija predstavljenoga u trilogiji.

Prije same analize narativne strukture potrebno je svratiti pozornost na dvije činjenice. Prvo, pojam kulturni imaginarij posuđujemo iz imagologije. ${ }^{1}$ Iz pozicije postmodernističkih teorija upravo identitet postaje važnim pitanjem imagologije i ideologije, a nacionalno obojen diskurs izražava se domoljubnim govorom i ispisuje se u imaginariju nacionalnih simbola. Upravo tako dolazimo do ideologema, riječi i sintagmi koje dobivaju simboličku vrijednost u određenome diskursu. ,Želje i strahovi stvaraju imagologiju, imagologija stvara ideologiju, ideologija stvara diskurs, diskurs stvara stereotipe kao posljednje, okamenjene identifikacijske točke, koje se naknadno naturaliziraju tj. pretvaraju u prirodne $\mathrm{i}$ autentične biti““ (Oraić Tolić 2006: 30).

Drugo, valja imati na umu kako se u slučaju Truhelkine trilogije radi o autobiografskome književnome diskursu u kojemu su ,procesi samorazumijevanja i samotumačenja najjasnije vidljivi““ (Zlatar 2004: 26). Trilogija ${ }^{2}$ Zlatni danci temeljni je tekst autobiografske proze hrvatske dječje književnosti, a ujedno pripada

1 Imagologija je istraživačka paradigma u znanosti o književnosti i kulturi koja se bavi istraživanjem $\mathrm{i}$ interpretativnom analizom diskursivnih konstrukcija kolektivnih identiteta, u prvome redu nacionalnih i etničkih, ali i vjerskih, socijalnih i rodnih. Svoj istraživački interes imagologija dijeli s mnogim suvremenim paradigmama društvenih i humanističkih znanosti, posebice sa socijalnom psihologijom, kulturnom antropologijom i postkolonijalnim studijima, osiguravajući si tako atribut iznimno kompleksne transdisciplinarne paradigme. U središtu je imagološkoga interesa kulturni imaginarij, a njegova (re)konstrukcija temeljna je zadaća imagološke analize. Takva analiza posebnu pažnju usmjerava na tekstualne, intertekstualne i kontekstualne odnose koji utječu na oblikovanje autopredodžbi (predodžbi/slika o vlastitoj zemlji i narodu) i heteropredodžbi (predodžbi/slika o stranim zemljama i narodima), ujedno i ključnih pojmova kulturnoga imaginarija. Francuski imagolog Daniel-Henri Pageaux (2009) smatra da bi rekonstrukcija kulturnoga imaginarija trebala dovesti do stvaranja niza slika/predodžbi koje bi trebalo povezati s društveno-kulturnim kontekstom te da kulturni imaginarij, kao i slika/predodžba, počiva na sustavu vrijednosti neke zajednice u danome povijesnome trenutku, odnosno na ideologiji. Otuda i uzročno-posljedična veza imagotipske predodžbe (Fischer 2009) i ideologema. Konkretnije, za razumijevanje određene predodžbe od ključne su važnosti ideologemi kulture kojoj promatrana predodžba pripada. U hrvatskoj znanosti o književnosti i kulturi imagološkim istraživanjima sustavno se bavi Davor Dukić koji je zajedno sa suradnicima priredio knjigu Kako vidimo strane zemlje. Uvod u imagologiju koja donosi prijevode devet kanonskih teorijskih tekstova poznatih europskih imagologa (usp. Dukić i dr. 2009).

2 Riječ je o trilogiji ili tetralogiji koja je izlazila u obliku triju odnosno četiriju knjiga: u prvome sastavu - Zlatni danci (1918.), Bogorodičine trešnje (1929.), Dusi domaćeg ognjišta (1930.); u drugome sastavu - Zlatni danci, Gospine trešnje (Bogorodičine trešnje i Dusi domaćeg ognjišta), Crni i bijeli dani, Zagreb (1942. - 1944.); u trećemu sastavu - Zlatni danci (1. i 2. knjiga), Bogorodičine trešnje (3. knjiga), Dusi domaćeg ognjišta (4. knjiga), Zagreb, 1995. 
najboljem dijelu Truhelkina stvaralaštva. Autorica u njemu opisuje svoje djetinjstvo provedeno u Osijeku šezdesetih i sedamdesetih godina 19. stoljeća, brižljivo i vrlo detaljno ocrtava ulicu svojega djetinjstva, prostor rodne kuće te niz likova koji su bili neizostavnim dijelom njezina djetinjstva koje je trajalo do 1878. godine kada se s obitelji preselila u Zagreb.

Andrea Zlatar navodi kako se upravo u autobiografskim tekstovima samooblikovanje identiteta događa u procesu pisanja, a tekst postaje prostorom oblikovanja identiteta: „Govorenje o prošlosti nije sumacija onoga što se dogodilo, nego intervencija u prošlost: ispovjedne strategije vremena stvaraju diskontinuitet $\mathrm{i}$ nezavisne efekte, umjesto kontinuiteta i kauzalnosti“ (2004: 27). Taj diskontinuitet, ili vremenska „skokovitost“ (Zima 2011: 51), uočljiv je u cijeloj Truhelkinoj trilogiji, a posebice dolazi do izražaja u Bogorodičinim trešnjama i Dusima domaćeg ognjišta u kojima je upravo asocijativnost temelj narativne organizacije. Navedeno sugerira i dvije dimenzije, odnosno dva načela takvih tekstova, fikciju i stvarnost, koje su u svojoj biti protuslovne. Načelo istinitosti, ako se samo i dijelom realizira u autobiografskome diskursu, odnosno ako je sama intencija pisanja istinita, moglo bi biti važan poticaj u rekonstrukciji autorova svijeta.

U kontekstu klasifikacije književnih vrsta trilogija se interpretira na dva načina, kao dječji roman i kao zbirka pripovijedaka. Znanstvenome kolebanju pridonosi epizodična kompozicija i nepostojanje jedinstvene fabularne poveznice. Dubravka Zima ipak navodi dvije dominantne kategorije integracijskoga načela u trilogiji: kategoriju prostora (fizičkoga i narativnoga) te kategoriju pripovjednoga obrasca koja se temelji na „nostalgičnom principu rekreiranja određenog vremena“ (2011: 49), što autorica povezuje s nazivom složeni roman koji rabe Maggie Dunn i Ann Morris u studiji The Composite Novel (1995).

Da je riječ o neuobičajenome autobiografskome govoru, potvrđuje i Andrijana Kos-Lajtman u knjizi Autobiografski diskurs djetinjstva. Autorica navodi kako je prvijenac autobiografske proze dječje književnosti Zlatni danci netipičan upravo iz razloga što se u njemu spajaju dva različita modusa pripovijedanja: ,autobiografski (historiografski) i romaneskni (fiktivni) - u jedinstvenu hibridnu inačicu dječje autobiografske proze“(2011: 133). Vodeći se Genetteovom tipologijom pripovjednoga diskursa, autorica trilogiju određuje kao „heterodijegetsku asocijativnu autobiografiju literariziranog tipa diskursa“ (isto), navodeći kako svojevrsna neočekivanost leži u činjenici da se izvantekstualni okvir i književni tekst ne podudaraju u imenu glavne junakinje (Jagoda - Anica). 


\section{Truhelkin kroatocentrični kulturni imaginarij}

Prvi dio trilogije pod naslovom Zlatni danci izlazi važne 1918. Godina je to završetka Prvoga svjetskoga rata, godina raspada Austro-Ugarske Monarhije i na koncu godina osnivanja prve jugoslavenske države. O tome turbulentnome razdoblju posvjedočila je i Truhelka u svojoj autobiografiji Iz prošlih dana nazivajući 1918. godinu „kobnom“ te, kako je autorica istaknula, ta je godina: ,za nas Hrvate najbolnija koju smo doživjeli““ (Truhelka 1970: 80). ${ }^{3}$ U svojemu radnome vijeku Truhelka je boravila u različitim sredinama (Osijeku, Gospiću, Zagrebu, Banjoj Luci, Sarajevu), a prostore svojega učiteljevanja označila je razdjelnim točkama autobiografije. Pomno iščitavajući njezinu autobiografiju, može se zaključiti kako se Truhelka svakom sredinom u kojoj je boravila koristila za brušenje/valoriziranje vlastitih stavova. Bitno je navesti kako u svojoj autobiografiji ističe nezaboravna predavanja profesora Hoića iz hrvatske povjesnice te će upravo hrvatska povjesnica u diskursu djela Zlatni danci postati ključnim ideologemom, svojevrsnim moralnim korektivom u svakodnevnim situacijama, počevši od bezbrižne dječje igre preko patriotskih poduka glavne junakinje do očeva pričanja u dugim zimskim večerima. Truhelka u svojoj autobiografiji navodi (1970: 62):

Tu su bili oni burni dani okolo kobne godine 1102., borbe o hrvatsku krunu i prijestolje, smrt Petra Svačića, nesuđenog posljednjega kralja tada još potpuno nezavisne Hrvatske, tu predstavnici dvanaest plemena hrvatskih na sudbonosnoj Dravi da sklope savez s Mađarima i da nakon krvave borbe sastave „pacta conventa“ - to najjače uporište naših prava na slobodu i nezavisnost hrvatskog kraljevstva - od kojih mi se najjače utisnula u svijest točka da se u hrvatskim zemljama ne smije naseliti ni jedan ne-Hrvat. Nije mi onda u mom rodoljubnom zanosu padalo na um da smo i ja i moja braća djeca stranih doseljenika.

Truhelka u autobiografiji također ističe i snažno očevo domoljublje, odnosno hrvatsku svijest koju je iskazivao podržavanjem reforme školstva, pohrvaćenja škola, ali i aktivnim sudjelovanjem u tome procesu; otac je kao stožerna figura patrijarhalno strukturiranoga Truhelkina osobnoga imaginarija predstavljen i u Zlatnim dancima. Dubravka Oraić Tolić u radu „Hrvatski kulturni stereotipi: Diseminacija nacije“ navodi kako je devetnaestostoljetna hrvatska kultura stvorila dvije ideologije i imagologije, što je onemogućilo stvaranje stabilnoga i jedinstvenoga nacionalnoga identiteta. Dvije su oprečne ideologije bile kroatocentrični imaginarij Ante

Usp. također: „Vijest o prekidu Hrvatske s Monarhijom zatekla me je u postelji gdje sam odbolovala gripu. Jedva što sam razabrala taj glas, počela sam svjesnije osjećati što znači: Hrvatska sloboda! O čemu sam od svoje desete nejasno sanjala i za čim sam žudjela kroz čitav život, to da se sada ispunilo? Ali kad sam prvi puta došla u školu iza bolesti, odmah sam znala - da je to tlapnja i da će nama Hrvatima zamalo svanuti još mnogi crni dani i da ćemo proživjeti teške godine" (Truhelka 1970: 80). 
Starčevića i jugoslavizam Josipa Jurja Strossmayera. Obje su ideologije stvorile „vlastiti patriotski govor i vlastiti simbolični svijet, s vlastitim tipom simboličnog subjekta, stalnim motivima i narativima" (Oraić Tolić 2006: 36). Više je nego očito kako Truhelka prati upravo ovu kroatocentričnu liniju nacionalnoga identiteta te svoj romaneskni svijet obogaćuje motivima i narativima koji se eksplicitno na njega referiraju. Narativni rekviziti slažu mozaik pripovjedne strukture, a među njima se zasigurno svojom učestalošću ističu očevi govori, ali i Aničini nostalgični patriotski iskazi koji se vrlo često referiraju na hrvatsku povijest. Konkretno, u prvoj knjizi Zlatni danci Anica s nostalgijom želi da njezina domovina bude jaka i sretna kakva je bila u vrijeme kralja Krešimira i kralja Zvonimira. U razgovoru Anice i njezinih prijateljica (Višnje i Dragice) o tome što bi poželjele da imaju zlatni prsten Anica odgovara kako bi željela (Truhelka 1995b: 198):

[...] da se pobiju svi naši dušmani i da nam se podiči naša domovina, da bude jaka i sretna kako je bila kad je živio kralj Krešimir i Zvonimir, i kako piše u povjesnici. Znate vi staru povjesnicu? Ja imam knjigu kod kuće, tata mi je dao i tamo svašta ima o starim Hrvatima.

Od hrvatskih povijesnih ličnosti posebno mjesto u očevim pričama, ali i u dječjim igrama, pripada banu Nikoli Zrinskome koji u Truhelkinoj trilogiji postaje ideologemom hrvatskoga otpora, ali i simbolom hrvatske hrabrosti i junaštva te pruža djeci primjer kako valja ljubiti i raditi „za svoju domovinu Hrvatsku“ (Truhelka 1995a: 186), što je itekako korespondiralo s društveno-političkom situacijom druge polovice 19. stoljeća, vremenom Truhelkina slavonskoga djetinjstva. Govoreći o Nikoli Zrinskome, važno je spomenuti kako je upravo njegov nacionalni identitet u 19. stoljeću bio problemsko pitanje iznimno pogodno za oblikovanje mišljenja i osjećaja. Tumačena iz hrvatske ideološke vizure opsada Sigeta bila je u prvome redu borba junaka hrvatskoga podrijetla, a hrabrost i žrtva Zrinskoga za domovinu u političkoj realnosti 19. stoljeća značila je i isticanje hrvatskoga identiteta usred habsburške dominacije (Palić-Jelavić 2012). ${ }^{4}$

Osim Zrinskoga, kao simbol hrvatske hrabrosti i junaštva u očevim pričama ističe se i ban Josip Jelačić. Malenome Dragošu posebno su zanimljive priče o njemu, a od oca traži da mu nacrta Jelačića sa svim nacionalnim obilježjima, „perjanicom na klobuku i s crveno-bijelo-plavim barjakom u ruci, a na vilovitu konju“" (Truhelka 1995a: 185). Na Dragoševo pitanje baki što joj je rekao ban Jelačić kad ga je vidjela kako prolazi kroz njezino selo, baka je znakovito odgovorila: „Što ti ja više znam? Imali smo mi posla s ukonačivanjem njegovih četa. Brzo su ti oni otišli opet pa put Drave i preko na drugi kraj [...]“"(186).

${ }_{4}$ S druge strane, drugačiji pogled na njegovo podrijetlo i obranu od Turaka imala je mađarska strana, koja ga smatra mađarskim junakom (usp. Bobinac 2006 i Palić-Jelavić 2012). 
Važni su ideologemi Truhelkina imaginarija prikazanoga u trilogiji i hrvatski nacionalni simboli (nacionalna himna i trobojnica). Lijepu našu domovinu djeca pjevaju na proslavi Prvoga svibnja dok okupljeni oko trobojnice koračaju gradskim ulicama. Kolika je za Truhelkine dječje likove bila važnost hrvatske zastave, potvrđuje i Dragoševo prvo sudjelovanje na svibanjskoj proslavi: ,[...] kako čvrsto korača kao pravi vojnik, kako mu se obrazi naduli od pjevanja a oči sjajne zapiljile u barjak i prate svaku kretnju njegovu. Što bi dao da on smije nositi barjak!“"(Truhelka 1995b: 105). Anica je i prije nego što je dobila novi klavir već na „fisharmonici“ jednim prstom znala odsvirati Lijepu našu domovinu. Domoljubne hrvatske pjesme (Gore nebo visoko, Glasna, jasna, Nek se hrusti šaka mala) djeca pjevaju u svim prilikama. Tako Anica u patriotskome zanosu započinje poznatu pjesmu Glasna, jasna, no njezine prijateljice Dragica i Višnja nisu je mogle pratiti jer je nisu znale.

U ovome kontekstu nezaobilazno je spomenuti i nacionalnu komponentu dječje igre koja vrlo jasno oslikava djecu, ambijent i vrijeme u kojemu žive. Dječja igra bitan je element narativne strukture dječjega romana. Crnković napominje kako je dječja igra ,priprema za kasniji život, podložna je sredini u kojoj djeca žive, duhu vremena, običajima koji vladaju i idejama kojima se ljudi zanose“ (1990: 131). Prikaz dječje igre u Truhelkinim Zlatnim dancima postaje prepoznatljivim elementom kulturnoga imaginarija, a najupečatljivija je ona koja se odvija jednoga četvrtka (na dan kada nema nastave) u poglavlju „Djeca se igraju“ koja umalo završava kobno. Potaknut učiteljevom pričom o Nikoli Zrinskome i opsadi Sigeta, Ćiro predloži da upravo taj događaj bude poticaj njihovoj igri. Djeca su se razdijelila na Hrvate i Turke, a da je hrvatska povjesnica korektiv i u dječjoj igri, potvrđuje Ćiro koji ističe kako Turaka mora biti mnogo više nego Hrvata jer je tako bilo i u povjesnici (Truhelka 1995b: 31):

Zgodnije igre ne bi znali ni svijećom naći. Nikola Zrinjski i opsada Sigeta! Istom neki dan pričao gospodin učitelj u školi o tom junaku. Samo tko će biti Nikola Zrinjski? Stali se dječaci otimati za tu čast. I zaprijetilo je već da će se zbog toga opet razvrgnuti lijepa sloga $[\ldots]$.

Važna je i Dragoševa ratna igra Hrvata protiv Talijana u kojoj su opet Hrvati bili junaci i istinski pobjednici. Ujedno je dječja simulacija sukoba Hrvata s Talijanima potaknula Đorđa da progovori o svojim iskustvima i sukobima s Talijanima koje je doživio. Đorđo se živo uklapa u kulturni imaginarij Zlatnih danaka. S pomoću Đorđova lika jasno se može nazrijeti društveni položaj Hrvata u Istri šezdesetih i sedamdesetih godina 19. stoljeća. Riječ je o epizodnome liku koji se pojavljuje u Bogorodičinim trešnjama, a s obzirom na to da je pripovjedno vrijeme organizirano asocijativno, u tome dijelu trilogije u središtu interesa upravo je njegova zanimljiva prošlost, vjenčanje s Kristinom i naposljetku smrt koja ga sprječava u želji za 
povratkom u rodni kraj. Da je kronološki tijek pripovijedanja poprilično narušen, potvrđuje i to što se nakon Đorđove i Kristinine životne priče pripovijedanje nastavlja u vremenu Ćirina i Dragoševa ranoga djetinjstva. Đorđo je prikazan kao pravi domoljub koji stradava zbog obrane časti i ugleda hrvatskoga nacionalnoga identiteta, vjerno se uklapajući i u nacionalnome i u socijalnome smislu u društvenopovijesnu sliku Istre sedamdesetih godina 19. stoljeća. ${ }^{5}$ Pojavljujući se kao novi drvosječa u školskome dvorištu, djeci je poprilično neobičan; u prvome redu zbog „velike kolaste naušnice“ koju nosi u lijevome uhu, a to ne nose muškarci u Slavoniji, ali i zato što Đorđo „govori sasvim drugojačije hrvatski nego što se govori u našem kraju i najposlije Đorđova pjesma zove se 'Vrbniče nad morem'“ (Truhelka 1995c: 89-90). Na početku šutljiv i tajnovit, sprijateljuje se s Dragošem gledajući njegovu ratnu igru u kojoj Hrvati pobjeđuju Talijane, što Đorđa vraća u dane kada je bio u ratu. U njegovoj tužnoj ispovijesti ${ }^{6}$ doznajemo kako je nastradao zbog pijanstva, odnosno ostao bez jednoga oka i lijeve noge. Razlog je bila prepirka s Talijanima o Viškoj bitci u kojoj mu je jedan Talijan rekao kako Hrvati nisu pobijedili Talijane kod Visa, pitajući se: „[...] jer otkuda onda da je Austrija morala Italiji predati Mletke i Milan i čitavu Lombardiju, ako je ona dobila bitku?“ (Truhelka 1995c: 110), nakon čega dolazi do tučnjave s tragičnim ishodom. Đorđo detaljno i vrlo živo djeci priča o svojemu sudjelovanju u Viškoj bitci 1866. godine u kojoj su Hrvati pod austrijskom zastavom pobijedili Talijane. U njegovoj uzbudljivoj priči sudjeluju i djeca svojim domoljubnim povicima. Tako Dragoš podržava Đorđovu izjavu kako su Hrvati junaci, izdvajajući Zrinskoga, Jurišića i Jelačića. Na kraju se nadovezuje i otac koji govori kako se čitalo po novinama o „divnom junaštvu naših Hrvata i kako je Nikola Krković čak strgao zastavu s jednog talijanskog broda i donio admiralu Tegethofu. Tako su doista dalmatinski ribari pobili gvozdene talijanske gorostase" (Truhelka 1995c: 108). Nadalje i Viška bitka kao simbol hrvatskoga junaštva i hrabrosti često je variran motiv u diskursu devetnaestoga stoljeća, posebice u Dalmaciji. U prvome redu poslužio je kao način da se Dalmatinci približe hrvatskome imenu, stoga se idealno uklapa u Truhelkin kroatocentričan

\footnotetext{
5 U nacionalnome smislu Đorđo se izjašnjava kao Hrvat iz Istre, što korespondira s tadašnjim jačanjem narodnoga pokreta u Istri kao rezultatom pritiska „talijanske buržoazije“ da Istri prida što više obilježja talijanskoga prostora, odnosno činjenicom kako se „u Italiji sve jače očituju težnje za priključenjem još 'neoslobođene' Istre“ (Šidak i dr. 1968: 112), a što Đorđo potvrđuje i u svojim pričama djeci. Njegov dolazak i socijalno je uvjetovan, a njegov socijalni status reflektira i razlike između sela i grada koje su tada u Istri bile vrlo izražene. Etnička opreka dodatno ih je osnaživala, građanstvo je gotovo u potpunosti bilo talijansko, dok je seljaštvo bilo većinom hrvatsko.

${ }^{6}$ U prepričavanju svojih zgoda Đorđo se osvrće na razgovor koji je vodio u bolnici u Genovi, uoči sukoba Italije s Austrijom. Iako Đorđa Talijani smatraju Talijanom, on se predstavlja kao Hrvat iz Istre. Na to mu je jedan Talijan odgovorio: „Pa Istra je talijanska zemlja, i mi ćemo je osloboditi, i nju i Dalmaciju i sve otoke!“ (Truhelka 1995c: 104-105). Đorđa je to strašno razljutilo te ih optužuje za otimanje, na što mu oni odgovaraju kako oni otimaju svoje.
} 
kulturni imaginarij. Viška bitka ${ }^{7}$ mnogim je književnicima 19. stoljeća poslužila i kao sredstvo poduke Istrana i Dalmatinaca u vezi s time kojoj naciji pripadaju te kako bi se nadvladale regionalne razlike. Očito je da i Truhelka dijeli takvo stajalište nacionalno atribuirajući Đorđa Hrvatom iz Istre. Na pitanje Aničina oca je li Primorac Đorđo odgovara: „Na službu, gospodine. Hrvat iz Istre - odgovori Đorđo dižući se sa stolice i stavši pred tatom u vojničku pozituru“ (Truhelka 1995c: 96). Zanimljivo je dodati kako se spomen na Višku bitku obilježavao do propasti Monarhije, a u vrijeme monarhističke i druge Jugoslavije zamijenile su ga proslave koje su pozivale na drukčiji povijesni imaginarij (Bermanec i dr. 2007).

\section{Prostorno markiranje Truhelkina kulturnoga identiteta}

Osim što je integracijski element narativne strukture, prostor, bilo otvoreni ili zatvoreni, otkriva se i kao važan pokazatelj kulturne (nacionalne) samoidentifikacije. Tako ambijent staroga Osijeka s ulicama, školom, crkvama i trgovima, rijekom Dravom kao „metaforom životnog ciklusa“ (Zima 2011: 50), ali i „sudbonosnim“ simbolom hrvatske povijesti, ${ }^{8}$ čiju važnost Truhelka naglašava i u autobiografiji i u trilogiji, predstavlja početni impuls u daljnjemu nacionalnome samopoimanju koje završava u širemu hrvatskome nacionalnome kontekstu.

Poslužimo li se trima veličinama horizontalnoga strukturiranja prostora $\mathrm{u}$ književnome tekstu o kojima Gabriel Zoran (1984) govori u članku „Towards a Theory of Space in Narrative“, tada bi navedene prostorne jedinice čijim nizanjem nastaje kompleks prostora bile signum totalnoga prostora u značenju svijeta teksta koji, za razliku od konkretnih prostornih jedinica i prostornih kompleksa, uključuje i prostorne elemente koji se impliciraju, ali se ne pokazuju izravno u tekstu. Širi nacionalni (hrvatski) prostor kod Truhelke se implicira naznačenim ideologemima i narativima. To se može povezati is tehnikom prikazivanja pripovjednoga prostora $u$ radu Katrin Dennerlein (2009), koja razlikuje prostor strukturiran pripovijedanjem događaja od prostora koji se posreduje spominjanjem prostornih činjenica u opisima, refleksijama, argumentacijama ili komentarima. Upravo u refleksijama, otvara se i implicira nacionalni kontekst koji je kod Truhelke kroatocentričan te značenje prostora postaje paradigmatsko na razini cijele trilogije. Govorimo li o konkretnim

7 O društvenim sjećanjima na Višku bitku i narativima koji se povezuju s njom detaljnije vidjeti Krešimir Bermanec i dr. (2007).

8 Djeca imaju posebno emotivan odnos prema Dravi: „Eh, da, divne velike rijeke! Puna puncata vode. Pružila se daleko i nalijevo i nadesno, pa se sjala na suncu kao rastaljeno srebro i bakar. I ove se njene vode nekamo žure niz maticu, pa ona teče i valja se kao da je živi stvor, pa šumi, grgolji, zapljuskuje o bijeli pijesak kao da ga miluje i hoće da razgovara sa zemljicom. Na drugom joj se kraju nanizali prekoputa suri ritovi i suri vrbici, a među njima bijeljele se seoske kućice kao koke u djetelini“ (Truhelka 1995a: 121-122). 
prostornim jedinicama, možda niti jedan (zatvoreni) prostor u trilogiji nije toliko zasićen nacionalno-hrvatskim ideologemima kao školski prostor na Gornjemu gradu. Upravo u taj nevelik prostor kao da je utisnuta gotovo cijela hrvatska povijest. U poglavlju „Anica i njena učiteljica“ u dijelu trilogije naslovljenome Dusi domaćeg ognjišta opisuje se školska soba. Na čitavome školskome zidu u sedam slika predstavljena je hrvatska povijest od dolaska Hrvata do smrti posljednjega hrvatskoga kralja. Truhelka se navedenim opisom koristi za pokretanje Aničinih domoljubnih misli, pri čemu i podučava (1995d: 61-62):

Anica je tužna kada gleda sliku smrti posljednjeg hrvatskog kralja, jer učila je gospođica da je veliki pokor za narod kojim ne vlada kralj njegova plemena i imena nego tuđin. I još ju je učila da je najveće zlo za narod ako je nesložan, i da bez sloge nema ni sreće ni napretka. Pa jer su stari Hrvati bili nesložni, zato su se morali pokoriti tuđemu vladaru i mnogo trpjeti od svakojakih neprijatelja. I zbog tih se neprijatelja Anica često zabrinula i u sebi žalostila i jadila.

I narativ hrvatske nesloge $\mathrm{i}$ jala zbog kojih hrvatska kruna prelazi na mađarsku glavu služio je dakle kao upozorenje na moguće posljedice nesloge i bio je iznimno aktualan tijekom 19. stoljeća. Salon, prostoriju koja je bila povezana sa školskom sobom, ukrašavale su slike hrvatskih velikana: „U sredini ban Mažuranić ozbiljno i strogo pogleduje svakoga tko spram njega podigne oči. Okolo bana eto ti Ljudevita Gaja, bana Jelačića, Ivana Gundulića, sve hrvatski velikani“ (Truhelka 1995d: 63).

Govoreći o nacionalnoj, neizostavno je spomenuti i religijsku komponentu prostora. Uz hrvatstvo, religioznost ${ }^{9}$ je temeljna označnica Truhelkina identiteta. Vjera u Truhelkinu stvaralaštvu nosi snagu trajne kulturne identifikacije, snažno utječe na život Aničine obitelji i u velikoj mjeri određuje naracijski tijek. Poglavlja su većinom određena nizom događaja koji se akumuliraju oko ključnih vjerskih blagdana (Badnjaka, Božića, Velike subote, Uskrsa) ili vjerskih običaja (procesija, hodočašća), što je prostorno itekako obilježeno. U pojedinim su poglavljima crkveni interijeri vrlo realistično opisani. ${ }^{10}$ Kao suprotnost realističnim opisima postojećih crkvenih interijera može se navesti potpuno apstraktan, ali kulturno proizveden prostor neba kako ga Anica doživljava. Anica je „sanjalica, a otvorenih očiju za stvarni svijet, buntovnik, pričalica i zanesenjak topla srca“"(Crnković 1997:

9 Detaljna analiza prostornih elemenata religioznosti ostaje izvan fokusa ovoga rada. Međutim, o važnosti religioznosti u Truhelkinu stvaralaštvu detaljnije su pisali Stjepan Hranjec (2003) i Ana Pintarić $(1998,2006)$.

${ }^{10}$ Kao primjer možemo navesti poglavlje „Uskrsna zvona“ $u$ kojemu se opisuje događanje na Veliku subotu i odlazak na procesiju u crkvu na Gornjemu gradu. Ispred crkve mali je trouglasti trg s kipom sv. Ivana na sredini: „U crkvi divna svjetlost. Što god je bilo svijeća, rasvjetnika, kandila: sve je bilo u najvećem sjaju. Oko glavnog oltara i povrh njega savio se vijenac od pozlaćena bršljana, a po vijencu bile pozaticane stotine i stotine svijeća, da ti je sve bliještilo ispred očiju, a sveti Mihalj, krasan junak na ovome svijetu, izišao na slici kao da je izrastao iz plamena, pa kopljem bije strašnoga zmaja“" (Truhelka 1995b: 24). 
274), često gleda i razmišlja o nebu, a u tim ga razmišljanjima i „oprostoruje“. U razgovoru s prijateljicom Milicom Anica nudi svoju dječju viziju neba (Truhelka 1995b: 72):

Dok sam bila mala, ja sam sebi zamišljala nebo kako kakav divan vilinski dvor, pun ogledala i cvijeća svakojaka. U najvećoj dvorani sjedi na crvenom prijestolju dragi Bog, oko njega anđeli, broja im ne znaš, vojske anđela, a na drugom kraju su preminule duše, u sredini opet sveci, svi se šeću po sjajnom podu ili sjede na divanima od crvena baršuna, pjevaju, razgovaraju se. Poslije sam mislila da nebo mora izgledati kao velika, velika i prekrasna crkva. Ali onda me spopadala muka, gdje bi mogla da stoji ta crkva? Pomisli, koliko je samo nebrojeno mnogo ljudi već pomrlo, a sve duše treba da stanu u nebo - razumije se - one bez grijeha. Negdje na kakovoj zvijezdi?

\section{Kuća Truhelkina djetinjstva}

Govori li se o kulturnome markiranju prostora, neizostavno je zaviriti u kuću Truhelkina djetinjstva ${ }^{11}$ koja postaje nositeljicom etičke dimenzije trilogije, ali i važnom komponentom u razotkrivanju Truhelkina imaginarija. U svojoj autobiografiji Truhelka navodi kako je iz roditeljske kuće ponijela uvjerenje o dobroti koje joj je u životu bilo nadahnućem, što unosi i u svoje književno stvaralaštvo. Njezina etika proizlazi iz vjerskoga i nacionalnoga osjećaja. Prema knjizi Poetika prostora Gastona Bachelarda (2000) čovjekov identitet otkriva se upravo u procesu (raz)otkrivanja mjesta na kojemu prebiva. S obzirom na to da je prostor u trilogiji „„̌ivljen“ (Lefebvre 1991: 356), odnosno da nije neutralan, on igra značajnu ulogu u oblikovanju autoričina kulturnoga identiteta. Upravo tematiziranjem emotivne povezanosti s određenim prostorom književnost posredstvom jezika pripomaže konstituiranju identiteta određenoga pisca. U trilogiji možemo posvjedočiti o tome kako upravo prostor kuće Truhelkina djetinjstva postaje nositeljem etičke dimenzije samoga djela. Radi se o patrijarhalno strukturiranim mikroprostorima koji imaju određene etičke/odgojne kodekse koji su itekako prostorno naglašeni. Svjedoči to i usporedba Aničine (Jagodine) kuće s kućom njezine prijateljice Melanke. Aničina kuća obilježena je nenametljivim redom i poštovanjem, skromnošću te likom oca kao stožernom figurom njezina identitetskoga svijeta, a Melankina kuća prikazuje se bogatijom i slobodnijom, s bitno labavijim granicama, bez pretjerane brige za određeni red i poštovanje (Melanka ima svoju sobu u kojoj sama spava, u božićno vrijeme Melankina kuća puna je gostiju te su sve sobe otvorene i gosti se kreću slobodno po njima). Shema na Sl. 1. prikazuje unutarnje prostorno ustrojstvo Aničine kuće s naglaskom na činjenici kako svaka soba/prostorija njihove obiteljske

${ }^{11}$ O ulozi prostora u Truhelkinim Zlatnim dancima izlagala sam na Šestome hrvatskome slavističkome kongresu održanome u Vukovaru i Vinkovcima od 10. do 13. rujna 2014. 
kuće nosi svoju priču ili svoj događaj te je gotovo u potpunosti obilježena likom (likovima) koji u njoj boravi/djeluje ili vjerskim/obiteljskim običajima za koje je namijenjena. U strukturi kuće autonomija prostora apsolutno se poštuje, što i potvrđuje Anica čudeći se „slobodi“ Melankinih gostiju, a prostor se poistovjećuje s osobama, tradicijskim običajima ili postaje nositeljem alegorijskoga značenja.

\section{STRUKTURA KUĆE}

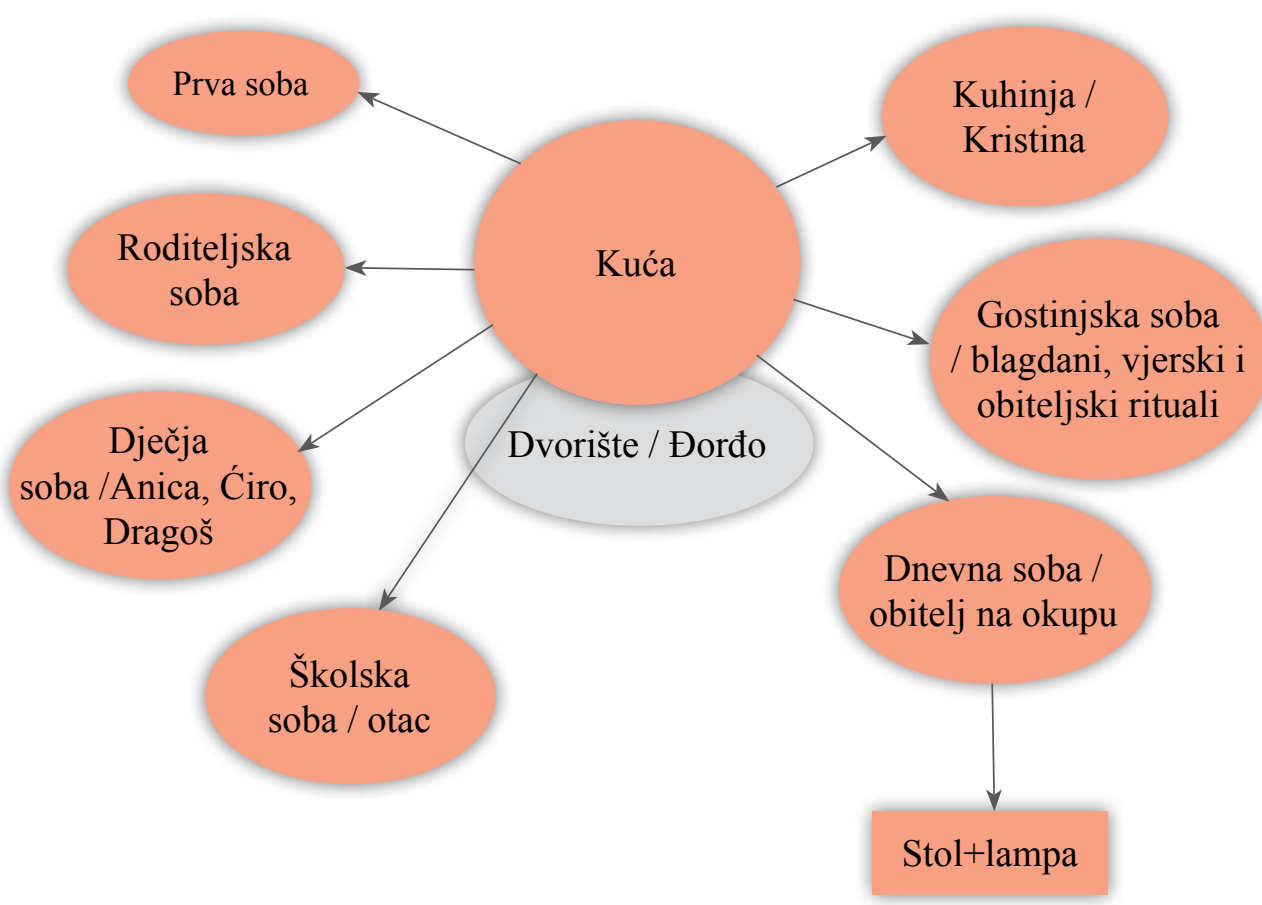

Sl. 1. Mikroprostori kao nositelji etičke dimenzije Zlatnih danaka (struktura gornjogradske kuće).

Fig. 1. Microspaces as carriers of the ethical dimension of The Golden Days (the structure of the Upper Town house).

Ovdje ćemo se osvrnuti samo na dva prostora koja možda najeksplicitnije popunjavaju kroatocentrični mozaik Truhelkina kulturnoga identiteta. Dnevna soba središnji je prostor u kojemu obitelj provodi najviše vremena. Za dugih zimskih večeri cijela obitelj okupljena je oko stola u dnevnoj sobi, svaki član smješten je na točno određenome mjestu s već ritualnom aktivnošću. Zimski ugođaj izvana osigurava pojačanu intimnost unutar kuće: „U toploj sobi nasred velikog okruglog stola gori lampa“ (Truhelka 1995a: 181). Upravo takva atmosfera postaje poticajna 
za pričanje i podučavanje djece koje većinom, kako smo naglasili, biva nadahnuto hrvatskom nacionalnom poviješću. Priče o banu Nikoli Zrinskom i banu Josipu Jelačiću te čitanje i prepričavanje biblijskih prispodoba i poučnih priča svoje prostorno utočište nalaze upravo u dnevnoj sobi tijekom dugih zimskih večeri. Otac, središnja figura obitelji, na kraju svojega pripovijedanja ističe činjenicu kako su „Hrvati bili junaci, kako su ljubili svoju hrvatsku domovinu, za nju se bili i krvcu lili“ (Truhelka 1995a: 186) te ne propušta priliku podučiti djecu: „Tako trebate i vi, djeco moja, da ljubite i da radite za svoju domovinu Hrvatsku!“” (isto). Ponekad se u ulozi pripovjedača pojavljuje i pomoćnica Kristina, čije biblijske priče djeca jako vole. Analizirajući biblijske prispodobe kao modele odgoja djece u Truhelkinoj trilogiji, Ana Pintarić (2006) ističe kako je odgojni postupak Aničina oca i neuke služavke jednak, naglašavajući kako oboje žele da djeca prepoznaju vlastitu situaciju ili postupke te da o njima promišljaju i donose sudove.

Također je važan i prostor gostinjske sobe. Ona je namijenjena isključivo blagdanima, dio je tradicije, blagdanskoga rituala koji je tako imao i svoje prostorno utočište. Bio je to uređeni/nedirnuti prostor koji je pružao određeno obilje i raskoš, što se moglo dopustiti samo u blagdansko vrijeme. U tu sobu djeca su smjela ući na uskrsnu nedjelju nakon doručka, a na prostrtome stolu dočekala bi ih uskrsna peciva, pisanice i šunka. Povrh divana na zidu u gostinjskoj sobi, s jedne i druge strane ogledala, visjeli su portreti majke i oca. U gostinjsku sobu ulazilo se i na Badnjak. Netom prije ponoći otac bi nestao kroz kuhinju, a nakon nekoliko trenutaka začulo bi se zvonce iz gostinjske sobe kao znak da se može doći (Truhelka 1995a: 204):

Ta ovakvoj se krasoti ni u najsmjelijim sanjama nisu nadali. Ne znaš kamo bi najprije pogledao. Onaj se bor posred sobe sjaji, blista kao da su po njemu pale sve same zvijezde nebeske, pa ti kradu i mame oči svojim svjetlucanjem. A tek ono što je bilo poredano pod drvetom i oko njega!

$\mathrm{Na}$ koncu, analitičko čitanje Truhelkine trilogije pokazalo je koliko je njezin diskurs zasićen nacionalno-hrvatskim ideologemima. Truhelka otvara vlastiti kulturni imaginarij koji pulsira između osječke Labudove ulice i širega hrvatskoga nacionalnoga konteksta te s pravom nosi atribut kroatocentričnosti. Osim eksplicitno prizivanih nacionalnih ideologema važno je bilo istaknuti i neke nacionalne motive i narative koji su mijenjali ideološki značaj ovisno o društvenopovijesnim okolnostima (Nikola Zrinski, Josip Jelačić, Hrvatsko Kraljevstvo, Viška bitka itd.), međutim u Truhelkinu slučaju oni su bili itekako bitan segment u njezinu književnome pozicioniranju unutar nacionalne književnosti. Analiza implicira kako imaginarij Zlatnih danaka ne reprezentira samo njihovu autoricu, već, u stanovitoj mjeri, i vrijednosti zajednice kojoj pripada. Ono što se zatječe u Zlatnim dancima, $\mathrm{u}$ Aničinu (Truhelkinu) slavonskome djetinjstvu, itekako korespondira s nacionalno 
obojenom drugom polovicom 19. stoljeća. Konkretno, Dalmacija i Istra tek tada doživljavaju svoj preporodni uzlet, čiju važnost Truhelka prepoznaje i podržava tada, ali i mnogo godina kasnije, kada se stvaralački, Zlatnim dancima, vraća u svoje djetinjstvo. Više su nego jasne poruke Aničina žučljiva odobravanja i podržavanja Đorđove priče, ali i konstantno isticanje junaštva Nikole Zrinskoga i vremena Hrvatskoga Kraljevstva, velikoga narativa hrvatskoga nacionalnoga imaginarija. U Truhelkinu stvaralaštvu oni su imali jasan cilj, ponajprije osnaživanje hrvatske nacionalne svijesti, poticanje osjećaja jedinstva i nacionalne homogenizacije hrvatskoga prostora.

\section{Literatura}

\section{Primarna literatura}

Truhelka, Jagoda. 1995a. Zlatni danci I. (ur. Joža Skok). Zagreb: Naša djeca. (Prvi put objavljeno 1918.).

Truhelka, Jagoda. 1995b. Zlatni danci II. (ur. Joža Skok). Zagreb: Naša djeca. (Prvi put objavljeno 1918.).

Truhelka, Jagoda. 1995c. Bogorodičine trešnje (ur. Joža Skok). Zagreb: Naša djeca. (Prvi put objavljeno 1929.).

Truhelka, Jagoda. 1995d. Dusi domaćeg ognjišta (ur. Joža Skok). Zagreb: Naša djeca. (Prvi put objavljeno 1930.).

\section{Sekundarna literatura}

Bachelard, Gaston. 2000. Poetika prostora. Prev. Zorica Ćurlin. Zagreb: Ceres.

Bermanec, Krešimir, Mario Katić, Tomislav Oroz i Nevena Škrbić Alempijević. 2007. „Sjećanje na Viški boj: proslave, spomenici, naracije“. Studia etnologica Croatica 19 (1): 77-127.

Bobinac, Marijan. 2006. „Körnerov Zrinski - Hrvat, Mađar ili Nijemac?“. U Kulturni stereotipi. Koncepti identiteta u srednjoeuropskim književnostima, ur. Dubravka Oraić Tolić i Ernő Kulcsár Szabó, 111-127. Zagreb: FF press.

Crnković, Milan. 1990. Dječja književnost. Priručnik za studente i nastavnike. Zagreb: Školska knjiga.

Crnković, Milan. 1997. „Pogovor“ U: Jagoda Truhelka. Zlatni danci. 273-276. Zagreb: Znanje.

Crnković, Milan i Dubravka Težak. 2002. Povijest hrvatske dječje književnosti: od početaka do 1955.godine. Zagreb: Znanje.

Dennerlein, Katrin. 2009. Narratologie des Raumes. Berlin/New York: De Gruyter

Dukić, Davor, Zrinka Blažević, Lahorka Plejić Poje i Ivana Brković, ur. 2009. Kako vidimo strane zemlje. Uvod u imagologiju. Zagreb: Srednja Europa.

Dunn, Maggie i Ann Morris. 1995. The Composite Novel. New York/Toronto: Twayne Publishers, Maxwell Macmillan Canada.

Fischer, Manfred S. 2009. „Komparatistička imagologija: za interdisciplinarno istraživanje nacionalno-imagotipskih sustava“. U Kako vidimo strane zemlje. Uvod u imagologiju, ur. Davor Dukić i dr., 36-56. Zagreb: Srednja Europa.

Hranjec, Stjepan. 1998. Hrvatski dječji roman. Zagreb: Znanje. 
Hranjec, Stjepan. 2003. „Jagoda Truhelka: vjera kao tradicijska baština“. U Kršćanska izvorišta dječje književnosti, 54-59. Zagreb: Alfa.

Kos-Lajtman, Andrijana. 2011. Autobiografski diskurs djetinjstva. Zagreb: Naklada Ljevak. Lefebvre, Henri. 1991. The Production of Space. Oxford-Cambridge: Blackwell.

Majdenić, Valentina. 2013. Regionalni tekst dječje književnosti. Zagreb: Naklada Ljevak.

Oraić Tolić, Dubravka. 2006. „Hrvatski kulturni stereotipi: Diseminacije nacije“. U Kulturni stereotipi. Koncepti identiteta u srednjoeuropskim književnostima, ur. Dubravka Oraić Tolić i Ernő Kulcsár Szabó, 29-45. Zagreb: Zavod za znanost o književnosti Filozofskog fakulteta u Zagrebu.

Pageaux, Daniel-Henri. 2009. „Od kulturnog imaginarija do imaginarnog“. U Kako vidimo strane zemlje. Uvod u imagologiju, ur. Davor Dukić i dr., 125-150. Zagreb: Srednja Europa.

Palić-Jelavić, Rozina. 2012. „Ideologemi u operi Nikola Šubić Zrinjski Ivana pl. Zajca“. Kroatologija 3 (1): 54-89.

Pintarić, Ana. 1998. „Život i djelo Jagode Truhelke - kako bih mogla da budem dobra“. U Zlatni danci 1 - Život i djelo Jagode Truhelke, ur. Ana Pintarić, 171-184. Osijek: HAZU, Zavod za znanstveni rad Osijek.

Pintarić, Ana. 2006. „Biblijske prispodobe kao model odgoja u trilogiji Zlatni danci Jagode Truhelke“. U Zlatni danci 7 - obitelj u književnosti za djecu i mladež, ur. Ana Pintarić, 141-156. Osijek: Filozofski fakultet Osijek, Filozofski fakultet Pečuh, Matica hrvatska.

Šidak, Jaroslav, Mirjana Gross, Igor Karaman i Dragovan Šepić. 1968. Povijest hrvatskog naroda g. 1860-1914. Zagreb: Školska knjiga.

Truhelka, Jagoda. 1970. „Autobiografija“. U Zlatni danci. Autobiografija (Pet stoljeća hrvatske književnosti, knjiga 107), 51-82. Zagreb: Matica hrvatska.

Zima, Dubravka. 2011. Kraći ljudi: povijest dječjeg lika u hrvatskom dječjem romanu. Zagreb: Školska knjiga.

Zlatar, Andrea. 2004. Tekst, tijelo, trauma: ogledi o suvremenoj ženskoj književnosti. Zagreb: Naklada Ljevak.

Zoran, Gabriel. 1984. „Towards a Teory of Space in Narrative“. Poetics Today 5 (2): 305335.

\section{Katarina Ivon}

University of Zadar, Croatia

Universität Zadar, Kroatien

\section{Zlatni danci by Jagoda Truhelka: An Example of a Croatocentric Cultural Imaginary}

According to Croatian children's literature historians, Crnković and Težak (2002), overstated Croatian patriotism and religiousness in Jagoda Truhelka's work were reasons for avoiding it in official school curricula during the era of both Yugoslav states. Thus, her work was often evaluated on an extraliterary basis. The author's autobiographical trilogy Zlatni danci [The Golden Days] is interpreted along these lines, to discern dominant 
motives and narratives which contribute to the reconstruction and interpretation of her cultural imaginary which may be described as Croatocentric. The author signals this by various means: Anica's didactic patriotic "tirades" learned at school, descriptions of the teacher's school and her salon, by reconstructions of children's play imitating the battle of Siget (Croats vs. Ottomans), by telling the story of lumberjack Đorđo (an Istrian Croat) and his significant role in the battle for Vis. The element of space is also important in the trilogy, both because of its integrative role and as a meaningful indicator of cultural self-identification. The analysis implies that the imaginary of The Golden Days represents not only its author's values, but also, to some extent, the values of the community that is represented.

Keywords: cultural imaginary, Jagoda Truhelka, Zlatni danci, national branding of space, Croatian children's literature

\section{Zlatni danci [dt. Goldene Zeiten] von Jagoda Truhelka als kroatozentrisches kulturelles Imaginarium}

Im Beitrag wird von den Gedanken aus der Geschichte der kroatischen Kinder- und Jugendliteratur von Crnković und Težak ausgegangen, wonach zum einen das in Truhelkas Werken enthaltene Kroatentum bzw. die darin dargestellte Religiosität zu Zeit Jugoslawiens (1918 - 1989) die Einreihung der Werke dieser Autorin in die Schullektüre verhinderten, zum anderen ihre Werke sehr oft anhand außerliterarischer Kriterien bewertet wurden. Auf der Spur dieser Gedanken wird im Beitrag die autobiographische Trilogie Zlatni danci der Autorin gedeutet, indem auf die dort dominierenden Motive und Erzählmuster eingegangen wird, die durch ihr häufiges Vorkommen der Rekonstruktion des kulturellen Imaginariums der Autorin, das man als kroatozentrisch bezeichnen könnte, beitragen. Dieses Imaginarium wird in der Trilogie durch verschiedene Erzählverfahren signalisiert: durch Anicas belehrend-patriotische, in der Schule erworbene „Tiraden“, durch Beschreibung der Schule und des Salons der Lehrerin, durch die Rekonstruktion des Kinderspiels, worin die Schlacht bei Siget nachgeahmt wird, sowie durch das Nacherzählen des Schicksals des Holzfällers Đorđe und seiner Teilnahme an der Schlacht bei der Insel Vis. In der Trilogie ist auch der Raum ein wichtiges Erzählelement, dem neben der integrativen Rolle auch die Funktion eines wichtigen Hinweises auf die kulturelle Selbstidentifikation eigen ist. Die Analyse impliziert, dass das Imaginarium von Zlatni danci nicht nur Werte der Autorin, sondern auch jene der Gemeinschaft, zu der die Autorin gehört, enthält.

Schlüsselwörter: kulturelles Imaginarium, Jagoda Truhelka, Zlatni danci, nationale Raummarkierung, kroatische Kinder- und Jugendliteratur 